\title{
KORELASI JUMLAH BATANG ROKOK DENGAN KADAR CO PADA REMAJA PEROKOK DI SMK KOTA JAMBI
}

\author{
Miko Eka Putri \\ Program Studi Ilmu Keperawatan STIKes Baiturrahim Jambi, Indonesia \\ Email : putri29iwan@gmail.com
}

\begin{abstract}
Cigarettes are very dangerous for health. The Global Adults Tobacco Survey (GATS) survey estimated that as many as 7.9 billion adults became active smokers and about 3.5 billion people were exposed to cigarette smoke at work. Indonesia ranks 4th out of 10 countries with a population of smokers (4\%) after China (38\%), Russia (7\%) and the United States (5\%) (Ministry of Health, 2012). Every cigarette smoked contains a lot of toxic substances, especially carbon monoxide $(\mathrm{CO})$ which can damage the sympathetic nervous system and hemoglobin desaturation.This study aims to see the effect of the number of cigarettes with CO levels in adolescent smokers in vocational schools. This research is a quantitative research with cross-sectional design. The sample in this study amounted to 20 people in which the sampling technique used was purposive sampling. This study was conducted on July 2018 in SMK in the city of Jambi. Analysis using the Wilcoxon test.The results showed that the average number of cigarettes smoked by teenagers per day was 3.2 cigarettes, and the average CO level was 10.1ppm. The results of the analysis with Wilcoxon test showed that there was an effect of the number of cigarettes on CO levels with a $p$ value of 0,000, meaning that there was a relationship between the number of cigarettes and CO levels in adolescent smokers in SMKs.The results of this study are expected to be a reference for teenagers to know the content of cigarettes and their dangers so that they can stop smoking behavior.

Key Word : the number of cigarettes, CO levels
\end{abstract}

\begin{abstract}
ABSTRAK
Rokok sangat berbahaya bagi kesehatan. Hasil survey Global Adults Tobacco Survey (GATS) memperkirakan sebanyak 7,9 milyar orang dewasa menjadi perokok aktif dan sekitar 3,5 milyar orang terpapar asap rokok di tempat kerja. Indonesia menempati urutan ke-4 dari 10 negara dengan jumlah penduduk perokok (4\%) setelah China (38\%), Rusia (7\%) dan Amerika Serikat (5\%) (DepKes, 2012). Setiap rokok yang dihisap mengandung banyak zat racun terutama karbonmonoksida(CO) yang dapat merusak susunan saraf simpatis dan desaturasi hemoglobin. Penelitian ini bertujuan untuk melihat korelasi jumlah batang rokok dengan kadar CO pada remaja perokok di SMK. Penelitian ini merupakan penelitian kuantitatif dengan desain crossectional. Sampel dalam penelitian ini berjumlah 20 orang dimana tekhnik pengambilan sampel purposive sampling. Penelitian ini dilakukan pada Juli 2018 di SMK yang ada di Kota Jambi. Analisis menggunakan uji wilcoxon. Hasil penelitian menunjukkan bahwa rata- rata jumlah rokok yang dihisap remaja setiap hari sebesar 3,2 batang rokok, dan rata- rata kadar $\mathrm{CO}$ 10,1 ppm. Hasil analisis dengan uji wilcoxon menunjukkan bahwa ada pengaruh jumlah rokok terhadap kadar $\mathrm{CO}$ dengan $\mathrm{p}$ value 0,000, artinya ada hubungan antara jumlah batang rokok dengan kadar CO pada remaja perokok di SMK. Hasil penelitian ini diharapkan dapat menjadi bahan acuan agar remaja tahu kandungan rokok dan bahayanya sehingga dapat menghentikan perilaku merokok.
\end{abstract}

Kata Kunci : Jumlah Batang Rokok, Kadar CO 


\section{PENDAHULUAN}

Global Adults Tobacco
Survey (GATS) memperkirakan
terdapat 7,9 milyar orang dewasa
saat ini perokok aktif dan 3,5 milyar
orang terpapar asap rokokdi tempat
kerja. Hampir 2/3 perokok di dunia
tinggal di 10 negara dan Indonesia
menempati urutan ke-4 dengan
jumlah perokok $(4 \%)$ setelah China
$(38 \%)$, Rusia $(7 \%)$ dan Amerika Serikat $(5 \%)^{1}$. Jumlah perokok lakilaki di dunia hampir 1 miliar orang, $35 \%$ berada di Negara maju dan 50\% berada di Negara berkembang, sedangkan sebanyak 250 juta wanita mengkonsumsi rokok di dunia. Pada tahun 2030, WHO memperkirakan jumlah kematian akibat rokok mencapai lebih dari 8 juta orang di seluruh dunia setiap tahunnya. Kematian akibat rokok saat ini sudah mendekati 6 juta orang pertahun, $80 \%$ kematian ini terjadi di negaranegara berkembang termasuk negara Indonesia ${ }^{2}$.

Menurut survei Riskesdas (2013),konsumsi rokok diIndonesia cenderung meningkat menjadi $(36,3 \%)$ di tahun 2013 yang awalnya hanya $(34,7 \%)$ pada tahun 2010. Perilaku merokok penduduk 15 tahun keatas masih belum mengalami penurunan dari 2007 ke 2013, melainkan cenderung meningkat dari34,2\% tahun 2007 menjadi $36,3 \%$ tahun $2013.64,9 \%$ laki-laki dan $2,1 \%$ perempuan masih menghisap rokok tahun 2013. Ditemukan $1,4 \%$ perokok umur 10 14 tahun,9,9\% perokok pada kelompok tidak bekerja, dan 32,3\% pada kelompok kuintil indeks kepemilikan terendah ${ }^{3}$.
Data dari Dinas Kesehatan

Provinsi Jambi (2016) memperlihatkan jumlah perokok remaja adalah sebanyak 394 orang. Perokok anak antara usia 10 hingga 14 tahun mencapai 1,2 juta orang.

Tandra (2006) menyebutkan bahwa $20 \%$ dari total perokok di Indonesia adalah remaja dengan rentang usia 15 hingga 21 tahun. Meningkatnya prevalensi merokok di Negara-negara berkembang, termasuk di Indonesia terutama di kalangan remaja menyebabkan masalah merokok menjadi semakin serius. Remaja mulai merokok dikaitkan dengan adanya krisis aspek aspek psikososial yang dialami pada masa perkembangannya yaitu masa ketika mereka sedang mencari jati diriny ${ }^{4}$.

Menurut Al Bachi Berbagai
fakta mengungkapkan bahwa semakin banyak remaja merokok maka semakin besar kemungkinan teman-temannya adalah perokok juga dan demikian sebaliknya. Dari fakta tersebut ada dua kemungkinan yang terjadi, pertama remaja tadi terpengaruh oleh teman-temannya atau bahkan teman-teman remaja tersebut dipengaruhi oleh diri remaja tersebut yang akhirnya mereka semua menjadi perokok. Diantara remaja perokok terdapat $87 \%$ mempunyai sekurang-kurangnya satu atau lebih sahabat yang perokok begitu pula dengan remaja non perokok $^{5}$.

Rokok yang dihisap memiliki dampak negatif terhadap tubuh manusia. Rokok sangat berpengaruh terhadap hemoglobin di dalam tubuh. CO juga dihasilkan dari asaprokok yang bisa mengakibatkan indoor air 
pollution (pencemaran didalam ruangan).Pencemaran udara dalam ruangan sangat berbahaya karena sumbernya berdekatan dengan manusia langsung. Hingga saat ini lebih dari 4.000 zat kimia telahdiketahui terkandung dalam asap rokok, termasuk didalamnya adalah $\mathrm{CO}^{6}$.

Hasil penelitian Inayatillah (2014) tentang kadar karbon monoksida udara ekspirasi pada perokok dan bukan perokok serta faktor-faktor yang mempengaruhi diketahui bahwa kadar $\mathrm{CO}$ pada perokok 22\%. Rekomendasi dari consensus European Respiratory Society (ERS) menyatakan bahwa kadar CO ekspirasi pada bukan perokok adalah $<4 \mathrm{ppm}^{7}$.

Penelitian Kumar dkk yang mendapatkan kadar $\mathrm{CO}$ pada bukan perokok sebesar 4,1 1 ppm lebih kecil bila dibandingkan dengan kadar perokok sebesar 15,6 \pm 7,1 ppm. Hasil penelitian Middleton dkk menggunakan kadar $\mathrm{CO} \leq 6 \mathrm{ppm}$ sebagai batasan untuk mereka yang bukan perokok. Perhimpunan Dokter Paru Indonesia dalam buku pedoman berhenti merokok menetapkan batasan $\leq 4$ ppm untuk kriteria bukan perokok dan $\geq 10$ ppm untuk kriteria perokok $^{8}$.

Berdasarkan data dari SMK Negeri Kota Jambi merupakan sekolah yang terdiri dari siswa lakilaki terbanyak dan remaja yang beresiko berperilaku merokok. Untuk itu penelitian akan dilakukan pada SMK Negeri Kota Jambi kelas X sebanyak 869, kelas XI sebanyak 549 dan kelas XII sebanyak 466, dan sebagian besar murid adalah lakilaki.

Berdasarkan survey awal yang dilakukan di SMK Negeri Kota
Jambi terhadap 10 siswa, sebanyak 9 siswa yang aktif merokok setiap hari dan hanya 1 yang tidak merokok, 5 dari 9 siswa yang merokok mengatakan merokok sejak SMP, 3 siswa mengatakan merokok sejak kelas 1 SMK, dan 1 orang mengatakan baru merokok saat naik kelas 2 SMK. 7 dari 9 siswa mengatakan merokok ketika berkumpul dengan teman-temannya, dan merokok di dalam rumah maupun diluar rumah, 2 siswa mengatakan merokok ketika berkumpul-kumpul diluar rumah saja dan tidak merokok dalam rumah. Dari hasil survey kepada beberapa siswa di SMK Kota Jambi menunjukkan bahwa 6 dari 10 siswa yang disurvey mempunyai kadar $\mathrm{CO}$ 7-10 ppm dan 5 siswa dengan kadar CO 01-06 ppm dan 7 dari 10 siswa merokok.

Berdasarkan hal inilah yang menjadi perhatian penulis untuk menindaklanjuti masalah tersebut dalam sebuah penelitian, maka penelitian ini berjudul pengaruh pendidikan kesehatan terhadap bahaya merokok bagi remaja perokok berdasarkan pengukuran kadar CO di SMK Kota Jambi.

\section{METODE PENELITIAN}

Penelitian ini adalah penelitian
kuantitatif dengandesain chi
Squaredengan tujuan melihat hubungan
jumlah batang rokok terhadap kadar CO
pada remaja perokok di SMK Kota
Jambi. Populasi pada penelitian ini
adalah seluruh siswa laki-laki yang
merokok sebanyak 1039 orang dan
Sampel yang di ambil adalah 20
responden dengan teknik
purposiveSampling. Penelitian ini
telah dilaksanakan di SMK Negeri 3
Kota Jambi pada tanggal 24 Juli-14


Agustus Tahun 2017. Hasil penelitian di analisis secara univariat dan bivariat menggunakan uji statistik korelasi

\section{HASIL DAN PEMBAHASAN}

\section{Hasil Univariat}

Hasil analisis univariat menunjukkan bahwa jumlah batang rokok dan kadar $\mathrm{CO}$ pada remaja SMK dapat dilihat pada tabel di bawah ini :

a. Distribusi Jumlah Batang Rokok

Tabel 1. Distribusi Frekuensi Jumlah Batang Rokok

\begin{tabular}{ccc}
$\begin{array}{c}\text { Jumlah } \\
\text { Batang } \\
\text { Rokok }\end{array}$ & Frekuensi & $\begin{array}{l}\text { Persentase } \\
\%\end{array}$ \\
\hline $1-4$ & & \\
$5-14$ & 15 & 75 \\
$>15$ & 5 & 25 \\
Total & 0 & 0 \\
\hline Betco & 20 & 100 \\
\hline
\end{tabular}

Berdasarkan hasil analisis univariat menunjukkan bahwa ada 2 remaja $(10,0 \%)$ merokok dengan jumlah batang rokok sebanyak 10 batangsehari. Dan hanya 6 remaja (30\%) merokok dengan jumlah batang rokok sebanyak 1 batang sehari. Hasil analisis univariat menunjukkan bahwa rata- rata jumlah batang rokok yang dihisap remaja setiap hari adalah 3,2 batang perharinya.

Kebiasaan merokok dapat merugikan diri sendiri dan orang lain yang berada disekitar. Asap rokok mengandung kadar $\mathrm{CO}$ dengan konsentrasi lebih dari 20.000 ppm. Selama dihisap, konsentrasi tersebut terencerkan menjadi 400-500 ppm. Sedangkan kadar $\mathrm{CO} \mathrm{Hb}$ lebih tinggi dari orang normal sekitar 2-15\% Merokok mengganggu kesehatan, banyak penyakit telah terbukti menjadi akibat buruk merokok, baik secara langsung maupun tidak langsung 5 .
Menurut Mahyudi, (2009) dampak perilaku merokok adalah 1). meningkatkan resiko timbulnya berbagai penyakit, seperti penyakit jantung dan gangguan pembuluh darah, kanker paru- paru, kanker rongga mulut, kanker laring, kanker esofagus, bronchitis, hipertensi, impotensi, gangguan kehamilan dan cacat janin. 2) dampak ekonomi dan dapak lingkungan ${ }^{5}$.

Menurut penelitian Rini Sundari dkk ( 2015) menyatakan bahwa jumlah rokok yang dikonsumsi oleh laki- laki perokok berkorelasi dengan lamanya merokok. Pada hasil penelitian ini memperlihatkan bahwa sebagian remaja perokok di SMK termasuk dalam kategori perokok ringan.

b. Distribusi Kadar CO

Tabel 2. Distribusi Frekuensi Kadar CO

\begin{tabular}{ccc}
$\begin{array}{l}\text { Kadar } \\
\text { CO(ppm) }\end{array}$ & Frekuensi Percentase \\
\% \\
\hline $1-6$ & 8 & 40 \\
$7-10$ & 4 & 20 \\
$11-30$ & 8 & 40 \\
Jumlah & $\mathbf{2 0}$ & $\mathbf{1 0 0}$ \\
\hline
\end{tabular}

Berdasarkan hasil distribusi kadar CO pada remaja diketahui bahwa sebagian remaja perokok (40\%) menghasilkan kadar $\mathrm{CO}$ antara 1-6 dan 11-30 ppm. Rata- rata kadar CO pada remaja yang perokok adalah $10,1 \mathrm{ppm}$ dengan standar deviasi 6,4 ppm.

Hasil penelitian ini sejalan dengan penelitian Kumar dkk yang mendapatkan kadar $\mathrm{CO}$ pada bukan

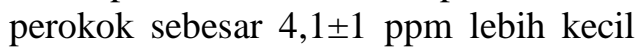
bila dibandingkan dengan kadar perokok sebesar 15,6 \pm 7,1 ppm.

Karbon Monoksida adalah gas tidak berwarna,tidak berasa, tidak berbau, tidak menyebabkan iritasi, mudah terbakar dan 
merupakan gas beracun. Sifat yang sulit untuk dideteksi ini menjadikan karbon monoksida dikenal sebagai silent killer. Dampak yang paling sering karena karbon monoksida biasanya pada pekerja yang terkena paparan karbonmonoksida ditempat kerja. Konsentrsi tinggi karbon monoksida dalam darah seseorang dalam hitungan menit dapat menyebabkan distress pernapasan dan kematian (Lingyun, 2013).

Pada hasil penelitian ini memperlihatkan bahwa sebagian remaja perokok di SMK termasuk dalam kategori perokok ringan.

\section{Hasil Bivariat}

Hasilanalisis dengan menggunakan uji korelasi yang bertujuan untuk melihat hubungan antara jumlah batang rokok dengan dapat dilihat pada tabel di bawah ini:

Tabel 3. Korelasi Jumlah Batang Rokok dengan kadar CO Remaja Perokok ( $n=20$ orang)

\begin{tabular}{llccc}
\hline & Mean & $\begin{array}{c}\text { Standar } \\
\text { Deviasi }\end{array}$ & $\begin{array}{c}\boldsymbol{P} \\
\text { value }\end{array}$ & $\boldsymbol{r}$ \\
\hline Jumlah & 3,2 & 2,82 & & \\
Batang & & & & \\
Rokok & & & 0,000 & 0,782 \\
Kadar & 10.10 & 6,41 & & \\
CO & & & & \\
\hline
\end{tabular}

Hasil penelitian menunjukkan bahwa rerata jumlah batang rokok yang dihisap oleh remaja setiap harinya adalah 3,2 batang dengan standar deviasi sebesar 2,82, sedangkan rerata kadar $\mathrm{CO}$ pada remaja perokok adalah 10,10 ppm dengan standar deviasi 6,41. Hasil uji statistik diperoleh nilai $\mathrm{r}=0,684$, dan nilai $\mathrm{p}$ value 0,000 . Berdasarkan hasil statistik dapat disimpulkan bahwa ada hubungan sangat kuat antara jumlah batang rokok dengan kadar CO pada remaja perokok. artinya semakin banak rokok yang dihisap oleh remaja, semakin tinggi kadar CO.

Hasil penelitian ini sejalan dengan penelitian yang dilakukan Inayatillah (2014) tentang kadar karbon monoksida udara ekspirasi pada perokok dan bukan perokok serta faktor-faktor yang mempengaruhi diketahui bahwa kadar CO pada perokok 22\%. Rekomendasi dari consensus European Respiratory
Society (ERS) menyatakan bahwa kadar CO ekspirasi pada bukan perokok adalah $<4$ ppm. Penelitian Kumar dkk yang mendapatkan kadar $\mathrm{CO}$ pada bukan perokok sebesar 4,1 1 ppm lebih kecil bila dibandingkan dengan kadar perokok sebesar 15,6 \pm 7,1 ppm. Hasil penelitian Middleton dkk yang menggunakan kadar $\mathrm{CO} \leq 6$ ppm sebagai batasan untuk bukan perokok. ${ }^{7}$

Karbon monoksida (CO) apabila terhisap ke dalam paru-paru akan ikut peredaran darah dan akan menghalangi masuknya oksigen yang dibutuhkan oleh tubuh. Hal ini dapat terjadi karena gas $\mathrm{CO}$ bersifat racun metabolis, ikut bereaksi secara metabolis dengan darah. Seperti halnya oksigen, gas CO mudah bereaksi dengan darah (hemoglobin). Merokok dengan tinggi nikotin, rendah nikotin atau tanpa nikotin, menyebabkan ikatan karbon monokida dengan haemoglobin ini meningkat.

Pembakaran tidak sempurna dari bahan organic didalam rokok meningkatkan $\mathrm{CO}$, yang diinhalasi dalam fase gas bersama dengan unsur asap lain yang volatil memapar darah paru ke kapiler paling sedikit 400 ppm CO. Karena afinitas haemoglobin terhadap CO kira-kira 245 kali lebih besar dari pada afinitasnya untuk $\mathrm{O} 2$, maka $\mathrm{CO}$ menggeser $\mathrm{O} 2$ dari haemoglobin yang menurunkan jumlah O2 yang ada bagi myocardium. Peningkatan $\mathrm{O} 2$ yang lebih kuat ke haemoglobin dengan adanya ikatan karbon monoksida dengan haemoglobin lebih mengurangi ketersediaan $\mathrm{O} 2$ bagi myocardium. Karbon monoksida juga bergabung dengan mioglobin dan dapat menunggu difusi $\mathrm{O} 2$ ke mitokondria otot jantung. Lebih jauh, CO bergabung langsung dengan sitokrom oksidase, yang memperlambat oksidasi nikotinamid- adenin- dinukliotida tereduksi. Apabila gas karbon dioksida memasuki sirkulasi darah, ia akan berikatan dengan hemoglobin sama seperti oksigen. Tetapi, ikatan karbon monoksida terhadap hemoglobin adalah 


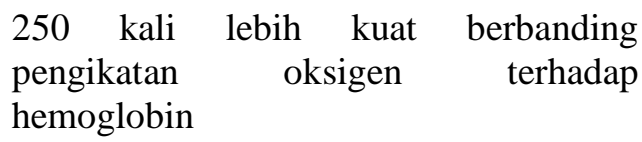

Pada konsentrasi sekecil $0.1 \%$ saja, karbon monoksida akan berikatan dengan separuh daripada total hemolgobin di dalam darah dan mengurangkan kapasitas membawa oksigen darah sebesar 50\%. Apabila hal ini berlanjutan, tubuh akan menjalankan mekanisme kompensasi berupa peningkatan proses erythropoiesis sebagai usaha untuk meningkatkan kadar penghantaran oksigen ke jaringan. Maka, kadar hemoglobin akan meningkat dan menjadi lebih tinggi berbanding pada kondisi normal. Salah satu penyebab terjadinya hipoksia akibat peningkatan kadar karbon monoksida adalah merokok ${ }^{9}$.

Kadar Monoksida (CO) dalam tubuh dangat berbahaya. Bahaya yang akan ditimbulkan dengan tingginya kadar karbon monoksida (CO ) dalam tubuh akan mengakibatkan banyak masalah kesehatan salah satunya adalah adanya gangguan pada sirkulasi darah dan jantung.

Untuk itu perlunya upaya remaja untuk berhenti merokok. Salah satu upaya berhenti merokok adalah melalui informasi yang diberikan kepada remaja, baik melalui media elektronik maupun melalui program pemberin pendidikan kesehatan tentang berhenti merokok. Suryanti (2009) menyatakan bahwa pendidikan kesehatan tentang berhenti merokok merupakan suatu metode yang mampu membantu sasaran untuk memahami dengan jelas pentingnya memberikan pengetahuan berhenti merokok. ${ }^{10}$ Hasil penelitian Evaprilia (2009) menunjukkan bahwa terdapat perbedaan tingkat pengetahuan dan motivasi responden penelitian saat sebelum dan sesudah dilakukan pendidikan kesehatan.

\section{SIMPULAN}

Hasil penelitian ini menunjukkan ada korelasi jumlah batang rokok dengan kadar CO pada remaja perokok di SMK Kota Jambi.

\section{SARAN}

Diharapkan hasil penelitian ini dapat menjadi dasar bahwa semakin banyak jumlah batang rokok yang dikonsumsi maka akan semakin tinggi kadar $\mathrm{CO}$ dalam tubuh remaja perokok, sehingga remaja harus berupaya keras berhenti merokok.

\section{Daftar Pustaka}

1. WHO. World Health

Organization.; 2011.

http://apps.nccd.cdc.gov/GTS

SData/Ancillary/DataReports.. aspx.

2. World Health Organization. Laporan Tahunan Angka Kejadian Kematian Akibat ISPA.(2013).

3. Kementrian Kesehatan Republik Indonesia. Riset Kesehatan Dasar ( Riskesdas). Jakarta; 2013.

4. Tandra. Merokok dan Kesehatan.http/\%5C://www.d omeclinic.com/lifestyle/merok ok-a-kesehatan. Published 2006.

5. Kemala. Perilaku Merokok Remaja. Medan: Program Studi Psikologi FK USU; 2007.

6. Fardiaz S. Pencemaran Air Dan Udara. Yogyakarta: Karnisius; 2006.

7. Inayatillah. Kadar Karbon 
Monoksida Udara Ekspirasi

Pada Perokok dan Bukan

Perokok Serta Faktor- Faktor

yang Mempengaruhi. 2014.

8. PDPI. Berhenti Merokok

Pedoman Penatalaksanaan

Untuk Dokter Di Indonesia.

Jakarta; 2011.

9. Adamson and L Longo.

Anemia and Polycythemia. JOM. 2008.

10. Suryanti. Pengaruh

Pendidikan Kesehatan

terhadap Pengetahuan dan

motivasi untuk berhenti

merokokpda sisw kelasII

SKMKota bimo. J UMS.

2009. 